\section{Land Suitability Evaluation and Economic Feasibility of Cocoa Farming}

Journal of Environmental Research Engineering and Management

Vol. 76 / No.3 / 2020

pp. 96-108

DOI 10.5755/j01.erem.76.3.24701
Received 2019/11

Accepted after revision 2020/08

\title{
Land Suitability Evaluation and Economic Feasibility of Cocoa Farming
}

\author{
Y.F. Syahri*, M. Rauf \\ Faculty of Agriculture, Universitas Sembilanbelas November Kolaka, Indonesia
}

\section{S.A. Paembonan, S.H. Larekeng}

Faculty of Forestry, Universitas Hasanuddin, Indonesia

*Corresponding author: yolandafitriasyahri@gmail.com

An evaluation of land suitability for cocoa cultivation was carried out in Southeast Sulawesi, Indonesia, according to its climatic conditions, as well as physical, morphological, and chemical soil characteristics. Land suitability evaluation is essential since cocoa production correlates positively with land characteristics. Purposive sampling with a survey method was used in this study. There were 11 sampling locations, comprising eight and three villages in North Kolaka and East Kolaka, respectively. Results showed that land suitability class for cocoa cultivation in North Kolaka is S2 (suitable) at 1,721 hectares in Pumbolo village and S1 (very suitable) in the other seven sampling locations, covering an area of 7,018 hectares in Rante Baru, Lasusua, Koroha, Watunohu, Lelehao, Tambuha, and Puurau village. Land suitability for cocoa production in all sampling locations in East Kolaka is S2 (suitable), covering an area of 11,213 hectares in Poli-Polia, Palenga Jaya, and Toasu village. The limiting factors in all sampling locations include $\mathrm{P}_{2} \mathrm{O}_{5}$ availability, humidity, and effective soil depth. Therefore, the addition of phosphorus fertilizers becomes one of the priority strategies to increase cocoa productivity. From an economic feasibility point of view, the R/C ratio in North Kolaka and East Kolaka is 1.56 and 2.12, respectively, which means that cocoa farming has a great potential to be developed in the two locations.

Keywords: cocoa, land suitability, economic feasibility. 


\section{Introduction}

Cocoa (Theobroma cacao L.) is one of the leading estate commodities in Indonesia, which plays a vital role in the economy of the country. Indonesia is the third-largest cocoa producer and exporter in the world, with a total export value of US\$ 1.24 billion. Southeast Sulawesi is the third-largest cocoa-producing province in Indonesia after South and Central Sulawesi, with an average production of 111,000 tons or $17.05 \%$ of total cocoa production in Indonesia (Kementerian Perindustrian, 2016). Areas in Southeast Sulawesi with the largest cocoa production are North Kolaka Regency $(58,630$ tons or $46.87 \%$ of the total cocoa production in Southeast Sulawesi) and East Kolaka Regency $(25,770$ tons or $20.6 \%$ of the total cocoa production in Southeast Sulawesi) (Setjen Pertanian, 2016). Cocoa farmers in the two areas are categorized as smallholders since they cultivate and manage their farm themselves. Currently, cocoa cultivation in North Kolaka and East Kolaka faces many obstacles in the field, including a high infestation of plant pests and low soil fertility. Soil nutrients under cocoa cultivation have been reduced enormously over time (Tenkap and Balogun, 2020). Consequently, cocoa farmers rely heavily on chemical fertilizers and pesticides. One of the problems in managing cocoa plantations is the extensive use of chemicals to keep or increase land productivity (Syarif, et al., 2020).

Optimum cocoa productivity can be achieved if it goes through the land suitability evaluation with criteria that reflect crop growth requirements for optimal production (Yatno, 2016). Land suitability evaluation is carried out by matching land characteristics and crop growth requirements. This evaluation is necessary, especially when planning the development of plantation commodities (Boix and Zinck, 2008), such as cocoa. In developing a cocoa plantation, some requirements need to be fulfilled, such as: (1) suitability of leading commodities in the development area; (2) potency of regional resources in the form of land, agro-climate, labor, and socio-economic facilities and infrastructure; as well as (3) socio-economic factor (Babalola et al., 2011).
Land suitability evaluation emphasizes on diversity of land characteristics since it will determine the type of crops or commodities which suit to be cultivated in a certain area. Land suitability evaluation also determines the level of land productivity (Neswati et al., 2019). Land suitability for a particular use is usually evaluated by its characteristics or quality (Kurnia et al., 2017). Land suitability criteria that are commonly used in Indonesia are general, since they are composed based on data compilation on land uses that are not site-specific.

Cocoa farmers in Indonesia generally do not know precisely how much profit and costs they are incurred during the production process. Considering the important role of cocoa plantations for farming communities in North Kolaka and East Kolaka as well as the national economy, evaluation of land suitability and economic feasibility of cocoa cultivation is required. Therefore, cocoa productivity can be enhanced, and inappropriate land use of the two districts can be avoided. This study aims to: 1) assess land suitability for cocoa growth based on climatic conditions as well as soil physical and chemical characteristics; and 2) analyze the economic feasibility of the development of cocoa plantation in North Kolaka and East Kolaka.

\section{Materials and Methods}

\section{Sampling method}

In the present study, the purposive sampling method was used (Sugiyono, 2001). Soil samples were taken at eight cocoa producing villages in North Kolaka, i.e., Pumbolo (Pl), Rante Baru (Rb), Lasusua (Ls), Koroha (Kh), Watunohu (Wh), Lelehao (Lh), Tambuha (Th), and Puurau ( $\mathrm{Pr}$ ), as well as three cocoa-producing villages in East Kolaka, i.e., Poly-Polia (Pp), Palenga Jaya (Pj), and Toasu (Tu). There were three observation points in each village (Figure 1). Twenty-two cocoa farmers were asked as respondents for the economic feasibility analysis of cocoa cultivation. 


\section{Data collection method}

The present study used both primary and secondary data. Data were collected through observation, documentation, laboratory tests, measurements in the field, and interviews. Evaluation of land suitability was determined based on a quantitative approach to scaling, i.e., by giving a scale score (0 to 3 ) (Table 1). In this scoring activity, each parameter of the existing land characteristics was categorized by classes based on the cocoa growth requirements (Djaenuddin et al., 2003) (Table 2). The more land suits the growing requirements of cacao, the higher score it has.
Conversely, if the land has lower suitability for cacao growth, it has a lower score. Physical soil characteristics include drainage, texture, rough material, effective soil depth, slope, flooding potential, and surface rocks. Chemical soil characteristics comprise cation exchange capacity (CEC), base saturation, $\mathrm{pH}$, organic carbon, total nitrogen, $\mathrm{P}_{2} \mathrm{O}_{5}, \mathrm{C}: \mathrm{N}$ ratio, and salinity. Climate characteristics include rainfall, the number of dry months, temperature, and humidity. A land suitability map was created by overlaying a basic map of the North Kolaka and East Kolaka regencies using ArcGIS 10.5 software.

Fig. 1. A map of research sampling coverage for cocoa land suitability landscapes in Southeast Sulawesi Province

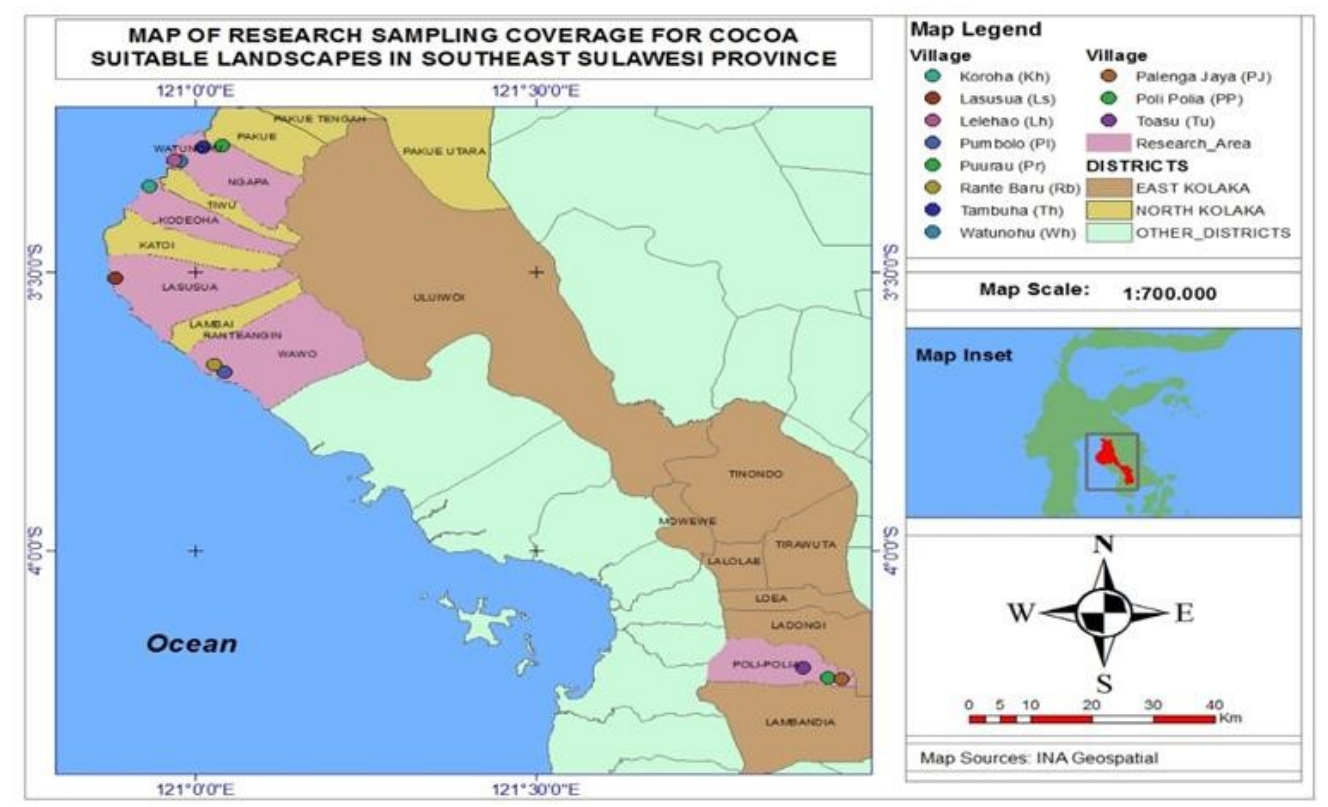

Table 1. Scoring the land suitability level

\begin{tabular}{|c|c|c|}
\hline Land suitability level & Symbol & Score \\
\hline Very suitable & $\mathrm{S1}$ & 3 \\
\hline Suitable & $\mathrm{S} 2$ & 2 \\
\hline Less suitable & S3 & 1 \\
\hline Not suitable & $\mathrm{N}$ & 0 \\
\hline
\end{tabular}


Table 2. Land suitability criteria for cocoa (Djaenuddin et al., 2003)

\begin{tabular}{|c|c|c|c|c|}
\hline \multirow{2}{*}{$\begin{array}{c}\text { Land } \\
\text { characteristics }\end{array}$} & \multicolumn{4}{|c|}{ Land suitability level } \\
\hline & $\mathrm{S} 1$ & $\mathrm{~S} 2$ & S3 & $\mathrm{N}$ \\
\hline \multicolumn{5}{|l|}{ Temperature (tc) } \\
\hline \multirow[t]{2}{*}{ Average annual temperature $\left({ }^{\circ} \mathrm{C}\right)$} & $25-28$ & $20-25$ & $32-35$ & $<20$ \\
\hline & & $28-32$ & & $>35$ \\
\hline $\begin{array}{l}\text { Water availability (wa) } \\
\text { Average annual rainfall (mm) } \\
\text { Number of dry (months) } \\
\text { Relative humidity (\%) }\end{array}$ & $\begin{array}{c}1500-2500 \\
1-2 \\
40-65\end{array}$ & $\begin{array}{c}2500- \\
3000 \\
2-3 \\
65-75\end{array}$ & $\begin{array}{c}1250-1500 \\
3000-4000 \\
3-4 \\
75-85\end{array}$ & $\begin{array}{c}<1250 \\
>4000 \\
>4 \\
>85\end{array}$ \\
\hline $\begin{array}{l}\text { Oxygen availability (oa) } \\
\text { Drainage }\end{array}$ & $\begin{array}{l}\text { good, } \\
\text { medium }\end{array}$ & $\begin{array}{l}\text { good, } \\
\text { medium }\end{array}$ & $\begin{array}{l}\text { obstructed, } \\
\text { rather fast }\end{array}$ & $\begin{array}{l}\text { very blocked, } \\
\text { fast }\end{array}$ \\
\hline \multicolumn{5}{|l|}{ Rooting media (rc) } \\
\hline \multirow[t]{2}{*}{ Soil texture } & smooth, rather & - & rather rough, very & rough \\
\hline & smooth, medium & & smooth & \\
\hline Coarse material (\%) & $<15$ & $15-35$ & $35-55$ & $>55$ \\
\hline Effective depth (cm) & $>100$ & $75-100$ & $50-75$ & $<50$ \\
\hline \multicolumn{5}{|l|}{ Danger of erosion (eh) } \\
\hline Slope (\%) & $<8$ & $8-16$ & $16-30$ & $>30$ \\
\hline Risk of flooding & FO & - & $\mathrm{F} 1$ & $>\mathrm{F} 1$ \\
\hline $\begin{array}{l}\text { Land preparation (lp) } \\
\text { Surface rock (\%) }\end{array}$ & $<5$ & $5-15$ & $15-40$ & $>40$ \\
\hline $\begin{array}{l}\text { Availability of nutrients ( } \mathrm{nr} \text { ) } \\
\mathrm{CEC}(\mathrm{cmol} \mathrm{kg-1)} \text { Base saturation(\%) } \\
\mathrm{pH} \mathrm{H}_{2} \mathrm{O} \\
\text { Organic carbon (\%) }\end{array}$ & $\begin{aligned} & >16 \\
& >35 \\
6.0 & -7.0 \\
& >1.5\end{aligned}$ & $\begin{array}{c}<16 \\
20-35 \\
5.5-6.0 \\
7.0-7.6 \\
0.8-1.5\end{array}$ & $\begin{array}{l}- \\
<20 \\
<5.5 \\
>7.6 \\
<0.8\end{array}$ & $\begin{array}{l}- \\
- \\
- \\
-\end{array}$ \\
\hline $\begin{array}{l}\text { Toxicity }(x c) \\
\text { Salinity }\left(\mathrm{dS} \mathrm{m} \mathrm{m}^{-1}\right)\end{array}$ & $<1.1$ & $1.1-1.8$ & $1.8-2.2$ & $>2.2$ \\
\hline
\end{tabular}


Economic feasibility analysis

Economic feasibility of cocoa farming was calculated by using the following formulas:

$$
\begin{aligned}
& \mathrm{I}=\mathrm{TR}-\mathrm{TC} \\
& \mathrm{TR}=\mathrm{Q} \times \mathrm{Pq} \\
& \mathrm{TC}=\mathrm{TVC}+\mathrm{TFC} \\
& \mathrm{R} / \mathrm{C}=\mathrm{TR} / \mathrm{TC}
\end{aligned}
$$

Whereas:

I = Revenue

$\mathrm{TR}=$ Total revenue

$\mathrm{TC}=$ Total cost

$Q \quad=$ Number of cocoa production $(\mathrm{kg})$

$\mathrm{Pq}=$ Price of cocoa per $\mathrm{kg}$ (Indonesian Rupiah)

TVC = Total variable cost

TF = Total fixed cost

$\mathrm{TR}=$ Total revenue

$\mathrm{TC}=$ Total cost

$\mathrm{R} / \mathrm{C}=$ Return $/$ cost ratio

Decision-making:

If the $\mathrm{R} / \mathrm{C}$ ratio > 1 , it means that the business is worth working out because it is profitable.

If the $\mathrm{R} / \mathrm{C}$ ratio $=1$, it means that the business is neither profitable nor losing.

If the $\mathrm{R} / \mathrm{C}$ ratio $<1$, it means that the business is not feasible to continue because it has a loss.

(Soekartawi, 2006).

\section{Results and Discussion}

\section{Climate characteristics}

The average of rainfall at the sampling locations in North Kolaka is in the range of $\pm 2509 \mathrm{~mm} /$ year, with nine wet months and three dry months. The climate type is B, according to Schmidt-Ferguson classification. The average air temperature and humidity are $27.87^{\circ} \mathrm{C}$ and $78.75 \%$, respectively. In East Kolaka, rainfall is in the range of $1542 \mathrm{~mm} /$ year, with seven wet months and five dry months. The average air temperature and humidity is $28.45^{\circ} \mathrm{C}$ and $75.83 \%$, respectively.

Cocoa is sensitive to drought. Therefore, the amounts of rainfall and its distribution within a year are an important consideration in cocoa cultivation. However, an area with an excessive amount of rainfall is also not desired. An annual rainfall above $2,500 \mathrm{~mm}$ will lead to soil nutrient leaching and impoverishment, as well as an increase in plant pathogens (Tenkap and Balogun, 2020). Ojo and Sadiq (2010) identified rainfall as the main factor responsible for decreasing the productivity of cocoa. The optimum relative humidity for cocoa is $40-65 \%$ (Djaenuddin et al., 2003). In the present study, both rainfall and humidity are not limiting factors for the growth and productivity of cocoa in the two research locations.

\section{Land unit characteristics}

Physical and chemical characteristics of land units

Soil physical characteristics comprehend drainage, texture, rough material, effective soil depth, slope, flooding potential, and surface rock. Chemical characteristics of the land units comprise CEC, base saturation, $\mathrm{pH}$, organic carbon, total nitrogen, $\mathrm{P}_{2} \mathrm{O}_{5}$, carbon: nitrogen ratio ( $\mathrm{C}: \mathrm{N}$ ratio), and salinity (Table $3 \mathrm{a}$ and $3 \mathrm{~b}$ ). In both North Kolaka and East Kolaka, soil drainage is categorized as good. This condition means that water can easily seep into the soil, although it is not occurring quickly. Good soil drainage is characterized by homogeneous soil without spot or iron rust, manganese, and agley color (reduction). Good soil drainage is desired since cocoa cannot grow better in water-logged conditions (PPKKI, 2010). Generally, cocoa can grow on various soil textures, but the good soil texture for cocoa is sandy clay loam, consisting of $30-40 \%$ of clay fraction, $50 \%$ of sand, and $10-20 \%$ of dust (Rubiyo and Siswanto, 2012). This soil texture has good water retention and air circulation (Liyanda et al., 2012). The soil texture in the two research locations varies, i.e., loam, sandy clay loam, sandy loam, clay loam, sandy silt loam, and silty clay. The effective depth of the soil is the depth at which plant roots can still enter the soil. The effective depth found in the study area is very shallow. This is indicated by the depth of the soil layer, which is found to be very shallow. A good soil layer depth for cocoa should be at least $90 \mathrm{~cm}$ to support the growth and development of the crop. Slopes in all sampling locations in both North Kolaka and East Kolaka are flat. The slope that can be recommended for agricultural development ranges within $0-3 \%$, $3-8 \%, 8-15 \%$, and $15-30 \%$. The risk of flooding in all 
Table 3a. Soil physical and chemical characteristics in eight sampling locations in North Kolaka (Pl=Pumbolo; Rb=Rante Baru; Ls=Lasusua; Kh=Koroha; Wh=Watunohu; Lh=Lelehao; Th=Tambuha; Pr=Puurau)

\begin{tabular}{|c|c|c|c|c|c|c|c|c|}
\hline \multirow{2}{*}{$\begin{array}{l}\text { Land } \\
\text { characteristics }\end{array}$} & \multicolumn{8}{|c|}{ Sampling location } \\
\hline & $\mathrm{Pl}$ & $\mathrm{Rb}$ & Ls & $\mathrm{Kh}$ & Wh & Lh & Th & $\operatorname{Pr}$ \\
\hline $\begin{array}{l}\text { Oxygen availability (oa) } \\
\text { Drainage }\end{array}$ & good & good & medium & good & rather slow & good & good & rather slow \\
\hline \multicolumn{9}{|l|}{ Rooting media (rc) } \\
\hline Soil texture & $\begin{array}{l}\text { sandy } \\
\text { loam }\end{array}$ & $\begin{array}{l}\text { clay } \\
\text { loam }\end{array}$ & $\begin{array}{l}\text { sandy- } \\
\text { silt-loam }\end{array}$ & silty-clay & silty-clay & silty-clay & silty-clay & silty-clay \\
\hline Coarse material (\%) & 0 & 0 & 0 & 0 & 0 & 0 & 0 & 0 \\
\hline Effective depth (cm) & $>40-60$ & $>40-60$ & $>40-60$ & $>40-60$ & $>40-60$ & $>40-60$ & $>40-60$ & $>40-60$ \\
\hline \multicolumn{9}{|l|}{ Erosion hazards (eh) } \\
\hline Slope (\%) & $0-3$ & $0-3$ & $0-3$ & $0-3$ & $0-3$ & $0-3$ & $0-3$ & $0-3$ \\
\hline Risk of flooding & very low & very low & medium & very low & medium & very low & very low & medium \\
\hline \multicolumn{9}{|l|}{ Land preparation (lp) } \\
\hline Surface rock (\%) & $<3$ & $<3$ & $<3$ & $<3$ & $<3$ & $<3$ & $<3$ & $<3$ \\
\hline \multicolumn{9}{|l|}{ Nutrient retention (nr) } \\
\hline $\operatorname{CEC}\left(\mathrm{cmol} \mathrm{kg}^{-1}\right)$ & 22.41 & 16.85 & 19.32 & 19.63 & 21.36 & 20.24 & 20.87 & 20.41 \\
\hline Base saturation (\%) & 44 & 64 & 57 & 54 & 43 & 54 & 50 & 53 \\
\hline $\mathrm{pH} \mathrm{H} \mathrm{H}_{2} \mathrm{O}$ & 6.8 & 7.1 & 6.8 & 6.6 & 6.9 & 6.8 & 6.9 & 7.2 \\
\hline Organic carbon (\%) & 1.72 & 1.18 & 1.32 & 0.87 & 0.98 & 1.08 & 1.32 & 1.58 \\
\hline Total nitrogen (\%) & 0.12 & 0.12 & 0.10 & 0.08 & 0.11 & 0.11 & 0.09 & 0.11 \\
\hline $\mathrm{P}_{2} \mathrm{O}_{5}$ (Olsen) (ppm) & 11.74 & 12.52 & 12.11 & 12.52 & 12.52 & 10.96 & 13.22 & 17.32 \\
\hline $\mathrm{C}: \mathrm{N}$ ratio & 14 & 10 & 13 & 11 & 9 & 10 & 15 & 14 \\
\hline Salinity $\left(\mathrm{dS} \mathrm{m}^{-1}\right)$ & 1.25 & 2.04 & 2.22 & 1.85 & 1.54 & 1.38 & 1.63 & 1.83 \\
\hline
\end{tabular}

sampling locations ranges from medium to low and very low level. According to the field observation, surface rock outcrops are less than $3 \%$ in all sampling locations, except in Toasu, East Kolaka, so that they do not become a limiting factor in cocoa cultivation.

The value of soil CEC in both North Kolaka and East Kolaka ranges from moderate (14.69 me $100 \mathrm{~g} \mathrm{~g}^{-1}$ ) to high (22.41 me $\left.100 \mathrm{~g}^{-1}\right)$. The higher the CEC, the higher the level of soil fertility because the number of available and exchanged cations will be increasingly used by plants (Anita-Sari and Susilo, 2012). Base saturation in all sampling locations in both North Kolaka and East Kolaka are categorized as high, ranging from 25 to $64 \%$. Soil pH in all sampling locations ranges within 5.5-7.2 or reacts slightly alkaline-neutral. Agricultural crops will generally grow and develop well in the $\mathrm{pH}$ range of $6-7$. In that $\mathrm{pH}$ range, essential nutrients in soils become available to meet crop needs. The ideal soil pH for cocoa is 6-7.5, and high soil organic matter (> 3\%) is desired (Mudgil and Barak, 2018). In all sampling locations, soil organic carbon content is high, and soil salinity is low. In general, the physical 
Table 3b. Soil physical and chemical characteristics in three sampling locations in East Kolaka (Pp=Poli-Polia; Pj=Palenga Jaya; Tu=Toasu)

\begin{tabular}{|c|c|c|c|}
\hline \multirow{2}{*}{$\begin{array}{l}\text { Land } \\
\text { characteristics }\end{array}$} & \multicolumn{3}{|c|}{ Sampling location } \\
\hline & $\mathrm{Pp}$ & $\mathrm{Pj}$ & Tu \\
\hline $\begin{array}{l}\text { Oxygen availability (oa) } \\
\text { Drainage }\end{array}$ & good & good & good \\
\hline \multicolumn{4}{|l|}{ Rooting media (rc) } \\
\hline Soil texture & sandy loam & loam & loam \\
\hline Coarse material (\%) & 0 & 0 & 0 \\
\hline Effective depth (cm) & $>40-60$ & $>40-60$ & $>40-60$ \\
\hline \multicolumn{4}{|l|}{ Erosion hazards (eh) } \\
\hline Slope (\%) & $0-3$ & $0-3$ & $0-3$ \\
\hline Risk of flooding & very low & very low & low \\
\hline \multicolumn{4}{|l|}{ Land preparation (lp) } \\
\hline Surface rock (\%) & $<3$ & $<3$ & $3-15$ \\
\hline \multicolumn{4}{|l|}{ Nutrient retention (nr) } \\
\hline CEC $\left(\mathrm{cmol} \mathrm{kg}^{-1}\right)$ & 14.69 & 16.22 & 18.25 \\
\hline Base saturation (\%) & 34 & 46 & 25 \\
\hline $\mathrm{pH} \mathrm{H} \mathrm{H}_{2} \mathrm{O}$ & 5.9 & 6.0 & 5.5 \\
\hline Organic carbon (\%) & 2.01 & 1.97 & 0.85 \\
\hline Total nitrogen (\%) & 0.14 & 0.12 & 0.07 \\
\hline $\mathrm{P}_{2} \mathrm{O}_{5}$ (Olsen) (ppm) & 9.63 & 10.74 & 8.36 \\
\hline C:N ratio & 14 & 16 & 12 \\
\hline Salinity $\left(\mathrm{dS} \mathrm{m}^{-1}\right)$ & 0.05 & 1.05 & 0.05 \\
\hline
\end{tabular}

and chemical characteristics of the land in the two research locations are good enough to support the growth and production of cocoa. Organic matter and nutrient retention are the soil characteristics that can be improved (Nasution et al., 2020).

\section{Land suitability assessment for cocoa farming}

Land suitability assessment on physical and chemical properties for cocoa farming according to Djaenuddin et al., (2003) in North Kolaka and East Kolaka are presented in Table $4 \mathrm{a}$ and Table $4 \mathrm{~b}$.

Based on land assessment value in Table $4 a$ and Table 4b, North Kolaka and East Kolaka have a range of very suitable land (S1) to suitable land (S2). In North Kolaka, a total study area of 7,018 ha including Rante baru, Lasusua, Koroha, Watunohu, Lelehao, Tambuha and Puurau were grouped as very suitable (S1) land, while 1,721 ha at Pumbolo village were categorized as suitable (S2) land (Figure 2a). In East Kolaka, a total study area of 11,213 ha at Poli-Polia, Palenga Jaya and Toasu village were considered suitable (S2) land (Figure $2 b$ ). A study from Erwiyono (2007) mentioned the importance of the land suitability value since it influences the cocoa productivity.

North Kolaka has an annual rainfall of $\pm 2,509 \mathrm{~mm} /$ year, distributed into 9 wet months and 3 dry months. 
Table 4a. Land assessment result on physical and chemical properties at eight sampling locations in North Kolaka (Pl=Pumbolo; Rb=Rante Baru; Ls=Lasusua; Kh=Koroha; Wh=Watunohu; Lh=Lelehao; Th=Tambuha; Pr=Puurau)

\begin{tabular}{|c|c|c|c|c|c|c|c|c|}
\hline \multirow{2}{*}{ Parameters } & \multicolumn{8}{|c|}{ Results at eight sampling locations* } \\
\hline & $\mathrm{Pl}$ & $\mathrm{Rb}$ & Ls & $\mathrm{Kh}$ & Wh & Lh & Th & $\operatorname{Pr}$ \\
\hline $\begin{array}{l}\text { Oxygen availability (oa) } \\
\text { Drainage }\end{array}$ & 3 & 3 & 2 & 3 & 1 & 3 & 3 & 1 \\
\hline \multicolumn{9}{|l|}{ Rooting media (rc) } \\
\hline Soil texture & 2 & 2 & 2 & 3 & 3 & 3 & 3 & 3 \\
\hline Coarse material (\%) & 3 & 3 & 3 & 3 & 3 & 3 & 3 & 3 \\
\hline Effective depth (cm) & 1 & 1 & 1 & 1 & 1 & 1 & 1 & 1 \\
\hline \multicolumn{9}{|l|}{ Erosion hazards (eh) } \\
\hline Slope (\%) & 3 & 3 & 3 & 3 & 3 & 3 & 3 & 3 \\
\hline Risk of flooding & 3 & 3 & 1 & 3 & 1 & 3 & 3 & 0 \\
\hline \multicolumn{9}{|l|}{ Land preparation (lp) } \\
\hline Surface rock (\%) & 3 & 3 & 3 & 3 & 1 & 3 & 3 & 3 \\
\hline \multicolumn{9}{|l|}{ Nutrient retention (nr) } \\
\hline $\mathrm{CEC}\left(\mathrm{cmol} \mathrm{kg}^{-1}\right)$ & 3 & 3 & 3 & 3 & 3 & 3 & 3 & 3 \\
\hline Base saturation (\%) & 3 & 3 & 3 & 3 & 3 & 3 & 3 & 3 \\
\hline $\mathrm{pH} \mathrm{H}_{2} \mathrm{O}$ & 3 & 2 & 3 & 3 & 3 & 3 & 3 & 2 \\
\hline Organic carbon (\%) & 3 & 2 & 2 & 2 & 2 & 2 & 2 & 3 \\
\hline Total nitrogen (\%) & 2 & 2 & 1 & 1 & 2 & 2 & 1 & 2 \\
\hline $\mathrm{P}_{2} \mathrm{O}_{5}$ (Olsen) (ppm) & 2 & 2 & 2 & 2 & 2 & 2 & 2 & 2 \\
\hline Salinity $\left(\mathrm{dS} \mathrm{m}^{-1}\right)$ & 3 & 3 & 3 & 3 & 3 & 3 & 3 & 3 \\
\hline
\end{tabular}

*) Values in the table represent the land suitability degree, where 1 - less suitable, 2 - suitable, 3 - very suitable.

The average temperature and humidity are $27.87^{\circ} \mathrm{C}$ and $78.75 \%$, respectively. Cocoa requires an annual rainfall of 1,100-3,000 $\mathrm{mm}$ with equal distribution throughout the year. The latter mentioned has a significant impact both on cocoa growth and its area expansion. According to the Schmidt-Ferguson climate classification, cocoa needs temperature between 30 $32^{\circ} \mathrm{C}$, between 3-4 months of dry month (DITJENBUN, $2011)$, the availability of water, sunlight, and humidity for better growth (Safuan et al., 2013). This study evaluated 1,721 ha of land at Pumbolo village $(\mathrm{Pl})$ in North Kolaka which is considered as suitable (S2), while other areas were categorized as very suitable (S1). However, the main limiting factor at Pumbolo village $(\mathrm{Pl})$ was that the humidity exceeded the ideal value for cocoa growth, around 40-65\% (Djaenudin et al., 2003), and it is nearly impossible to modify humidity.
Another factor is the shallow depth of topsoil followed by a thick layer of subsoil also responsible for inhibiting cocoa growth, as the thick layer is impenetrable, causing a root penetration problem in absorbing nutrients and water from soil.

In East Kolaka, all the study area was considered as suitable land (S2). The annual rainfall is $\pm 1,542 \mathrm{~mm} /$ year divided into 7 wet months and 5 dry months. The average temperature and humidity are $28.45^{\circ} \mathrm{C}$ and $75.83 \%$, respectively. More cocoa growth constraints are associated with the S2 land suitability class, and thus to maintain the cocoa productivity and profit, additional agricultural inputs or improvements should be taken into consideration (DITJENBUN, 2011). This study revealed that the limiting factors in East Kolaka are temperature, dry month, topsoil depth and availability of $\mathrm{P}_{2} \mathrm{O}_{5}$, where temperature and dry month are 
Table 4b. Land assessment result on physical and chemical properties at three sampling locations in East Kolaka (Pp=Poli-Polia; Pj=Palenga Jaya; Tu=Toasu)

\begin{tabular}{|c|c|c|c|}
\hline \multirow{2}{*}{ Parameters } & \multicolumn{3}{|c|}{ Results at eight sampling locations* } \\
\hline & $\mathrm{Pp}$ & $\mathrm{Pj}$ & Tu \\
\hline $\begin{array}{l}\text { Oxygen availability (oa) } \\
\text { Drainage }\end{array}$ & 3 & 3 & 3 \\
\hline \multicolumn{4}{|l|}{ Rooting media ( $r c$ ) } \\
\hline Soil texture & 2 & 2 & 2 \\
\hline Coarse material (\%) & 3 & 3 & 3 \\
\hline Effective depth (cm) & 1 & 1 & 1 \\
\hline \multicolumn{4}{|l|}{ Erosion hazards (eh) } \\
\hline Slope (\%) & 3 & 3 & 3 \\
\hline Risk of flooding & 2 & 2 & 2 \\
\hline \multicolumn{4}{|l|}{ Land preparation (lp) } \\
\hline Surface rock (\%) & 3 & 3 & 2 \\
\hline \multicolumn{4}{|l|}{ Nutrient retention (nr) } \\
\hline $\mathrm{CEC}\left(\mathrm{cmol} \mathrm{kg}^{-1}\right)$ & 2 & 3 & 3 \\
\hline Base saturation (\%) & 2 & 3 & 2 \\
\hline $\mathrm{pH} \mathrm{H} \mathrm{H}_{2} \mathrm{O}$ & 2 & 2 & 2 \\
\hline Organic carbon (\%) & 3 & 3 & 2 \\
\hline Total nitrogen (\%) & 2 & 2 & 1 \\
\hline $\mathrm{P}_{2} \mathrm{O}_{5}$ (Olsen) (ppm) & 1 & 2 & 1 \\
\hline Salinity $\left(\mathrm{dS} \mathrm{m}^{-1}\right)$ & 3 & 3 & 3 \\
\hline
\end{tabular}

*) Values in the table represent the land suitability degree, where 1 - less suitable, 2 - suitable, 3 -very suitable.

Fig. 2a. A land suitability map for cocoa farming in North Kolaka, Southeast Sulawesi, Indonesia

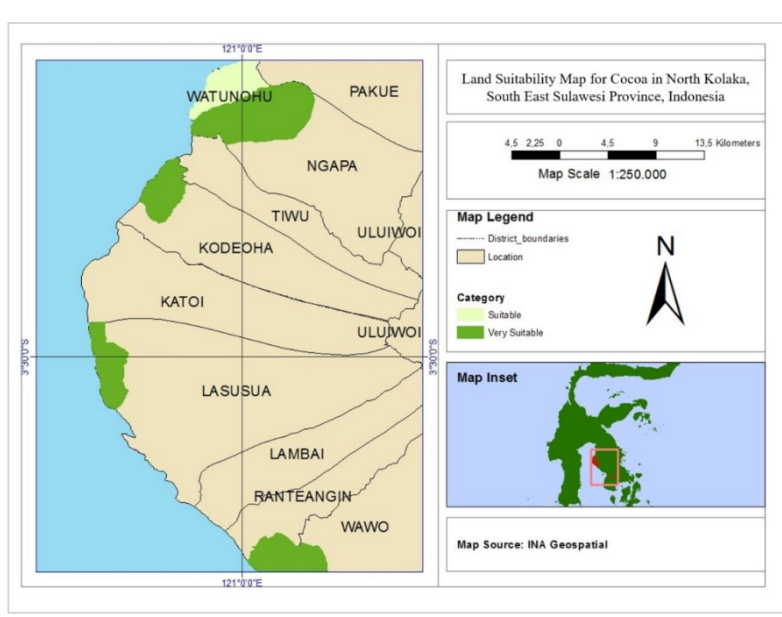

Fig. 2b. A land suitability map for cocoa farming in North Kolaka, Southeast Sulawesi, Indonesia

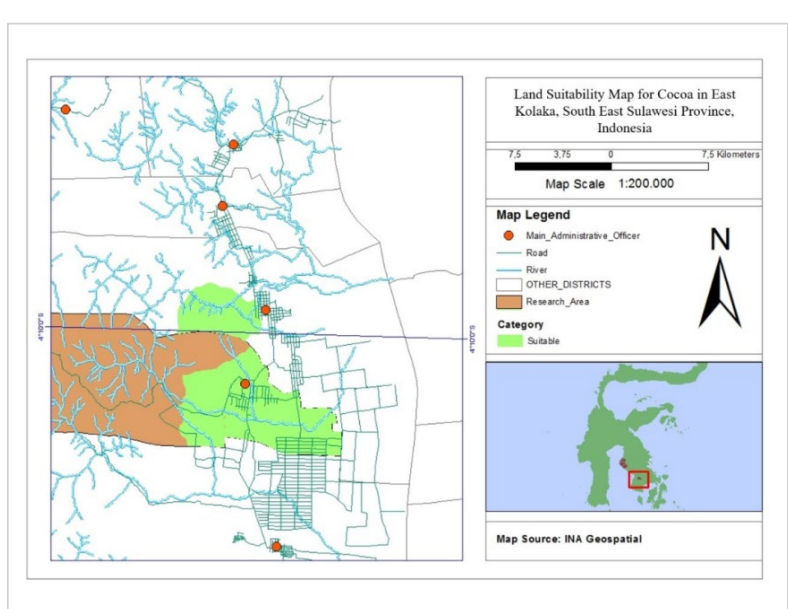


factors that are hardly possible to be modified. The lacking availability of $\mathrm{P}_{2} \mathrm{O}_{5}$ can be improved by soil amendment through organic and inorganic material and balanced fertilization and in the long term can solve the limiting factors, i.e., nutrient retention and nutrient availability (Anwar et al., 2019; Tri et al., 2018). Those phosphorus nutrients are essential for crop and root development as needed in the photosynthesis process (Havlin et al., 1999).

Generally, cocoa is able to grow on various types of soil, while soil chemical (soil acidity $(\mathrm{pH})$, organic matter content) and physical properties (topsoil depth, drainage, soil texture, soil aggregate) play an important role in supporting the cocoa growth (Ramlan et al., 2020).

\section{Economic feasibility analysis of cocoa farming}

\section{Production costs}

The data for economic feasibility analysis was obtained from interviews of total twenty-two respondents, spread over sixteen respondents and six respondents from North Kolaka and East Kolaka, respectively. Results showed that the average farmer's landholding was 1 ha in North Kolaka, and a larger landholding of 2.8 ha in East Kolaka. Production cost, which consists of fertilizer, herbicide, and labor cost, was spent by farmers themselves. The average production cost was IDR 1,860,000 and IDR 3,731,666 per study locations in North Kolaka and East Kolaka, respectively (Table 5 and Table 6). In both study areas, labor cost dominated the portion of production cost, due to manual (human) labor and use of non-mechanized equipment on the cultivation, fertilization, and harvesting process. The average daily wage of the labor was between IDR 150,000 and 250,000, while the number of workers depends on how large the farming area. The fertilizer cost was the second dominant production cost, since several types of nitrogen, phosphor, and potassium fertilizers were applied, as well as pesticides and herbicides. Cocoa farmers in North Kolaka and East Kolaka were contingent on those inputs to maintain the cocoa productivity yet on the other side increasing the production cost.

Table 5. Average production costs at each farming location

\begin{tabular}{|c|c|c|c|}
\hline \multicolumn{4}{|c|}{ North Kolaka } \\
\hline No. & Description & Total farm costs (IDR) & Average cost per farming (IDR) \\
\hline 1 & Fertilizers (NPK, urea, ponska, KCl, ZA, SP36) & $12,440,000$ & 777,500 \\
\hline 2 & Pesticides & $4,520,000$ & 282,500 \\
\hline 3 & Labor & $12,800,000$ & 800,000 \\
\hline & Total amount & $29,760,000$ & $1,860,000$ \\
\hline \multicolumn{4}{|c|}{ East Kolaka } \\
\hline 1 & Fertilizers (NPK, urea, ponska, KCl, ZA, SP36) & $8,840,000$ & $1,473,333$ \\
\hline 2 & Pesticides & $4,050,000$ & 675,000 \\
\hline 3 & Labor & $9,500,000$ & $1,583,333$ \\
\hline \multicolumn{2}{|r|}{ Total amount } & $22,390,000$ & $3,731,666$ \\
\hline
\end{tabular}

Total revenue of cocoa farming

Cocoa farming revenue was calculated based on the cocoa production and the market selling price. The total revenue of cocoa farming in North Kolaka and East Kolaka per harvest were IDR 46,410,000 and IDR 47,500,000, respectively. While converted into the revenue per hectare, the revenue in North Kolaka and East Kolaka became IDR 2,900,625 and IDR $2,827,380$, respectively, which accounted from 1,820 $\mathrm{kg}$ and $1,900 \mathrm{~kg}$ of the total production per harvest season in North Kolaka and East Kolaka, respectively (Table 7). 
Table 6. Average production costs per hectare

\begin{tabular}{|c|c|c|c|}
\hline \multicolumn{4}{|c|}{ North Kolaka } \\
\hline No. & Description & Total farm costs (IDR) & Average cost per hectare (IDR) \\
\hline 1 & Fertilizers (NPK, urea, ponska, KCl, ZA, SP36) & $12,440,000$ & 777,500 \\
\hline 2 & Pesticides & $4,520,000$ & 282,500 \\
\hline 3 & Labor & $12,800,000$ & 800,000 \\
\hline & Total amount & $29,760,000$ & $1,860,000$ \\
\hline \multicolumn{4}{|c|}{ East Kolaka } \\
\hline 1 & Fertilizers (NPK, urea, ponska, KCl, ZA, SP36) & $8,840,000$ & 526,190 \\
\hline 2 & Pesticides & $4,050,000$ & 241,071 \\
\hline 3 & Labor & $9,500,000$ & 565,476 \\
\hline & Total amount & $22,390,000$ & $1,332,737$ \\
\hline
\end{tabular}

Table 7. Total revenue of cocoa farming

\begin{tabular}{|c|c|c|c|c|}
\hline \multicolumn{5}{|c|}{ North Kolaka } \\
\hline No. & Description & Total Revenue of cocoa farming & $\begin{array}{l}\text { Average revenue } \\
\text { per farming }\end{array}$ & $\begin{array}{c}\text { Average revenue } \\
\text { per hectare }\end{array}$ \\
\hline 1 & Production (kg) & 1,820 & 113,75 & 113,75 \\
\hline 2 & Price of production (IDR/kg) & $24,000-27,000$ & 25,500 & 25,500 \\
\hline 3 & Revenue (IDR) & $46,410,000$ & $2,900,625$ & $2,900,625$ \\
\hline \multicolumn{5}{|c|}{ East Kolaka } \\
\hline 1 & Production (kg) & 1900 & 316,66 & 113,09 \\
\hline 2 & Price of production (IDR/kg) & $20,000-30,000$ & 25,000 & $1,488,09$ \\
\hline 3 & Revenue (IDR) & $47,500,000$ & $7,916,500$ & $2,827,380$ \\
\hline
\end{tabular}

\section{Net income and revenue to cost ratio $(R / C)$}

Net income means the difference between the total revenue and production costs. This study found that the net income from cocoa farming in North Kolaka and East Kolaka was IDR 1,040,625, and IDR 4, 184,834, respectively (Table 8 ). The $\mathrm{R} / \mathrm{C}$ ratio for both study areas was above 1, which means that cocoa farming activities in North Kolaka and East Kolaka are feasible.

Cocoa farming in North Kolaka and East Kolaka is fully managed by farmers' community, in a subsistence way rather than as a business. It means that the income they gained from the farming was used to meet the daily household needs, and in a small portion, invested in the next production process. Based on the R/C ratio value 1.56 in North Kolaka and 2.12 in East Kolaka, it theoretically represents that cocoa farming is profitable and contributes to farmers' income even though it is not substantial. However, cocoa farming is still considered feasible and profitable to be cultivated (Ermiati et al., 2014). According to this study, cocoa farming is feasible to be developed in North Kolaka and East Kolaka. To increase the yield, cocoa plantations can implement 
Table 8. Net income and $R / C$ ratio

\begin{tabular}{l|l|l|l}
\multicolumn{2}{|c}{ Description } & \multicolumn{1}{c}{ North Kolaka } \\
\hline No. & \multicolumn{1}{|c}{ Average income per farming (IDR) } & \multicolumn{1}{c}{ Average income per hectare (IDR) } \\
\hline 1 & Total revenue & $2,900,625$ & $2,900,625$ \\
\hline 2 & Production costs & $1,860,000$ & $1,860,000$ \\
\hline 3 & Net income & $1,040,625$ & $1,040,625$ \\
\hline 4 & R/C ratio & 1.56 & 1.56 \\
\hline & & \multicolumn{1}{|c}{ East Kolaka } \\
\hline 1 & Total revenue & $7,916,500$ & $2,827,380$ \\
\hline 2 & Production costs & $3,731,666$ & $1,332,737$ \\
\hline 3 & Net income & $4,184,834$ & $1,494,643$ \\
\hline 4 & R/C ratio & 2.12 & 2.12 \\
\hline
\end{tabular}

rehabilitation, rejuvenation, and expansion of areas, which is supported by high-quality cocoa seeds and the application of advanced technology. Furthermore, post-harvest processing technology is an excellent consideration to be implemented for maintaining the quality of cocoa to fit with the market demands, thus increasing its selling price.

\section{Conclusions}

Amongst eight sampling locations in North Kolaka, an area of 1,721 hectares in Pumbolo village is classified as S2 or suitable for cocoa cultivation, and the other areas of 7,018 hectares in Rante baru, Lasusua, Koroha, Watunohu, Lelehao, Tambuha, and Puurau village are categorized as S1 or very suitable for

\section{References}

Anita-Sari, I., and Susilo, A. W. (2012) Keberhasilan Sambungan Beberapa Jenis Batang Atas dan Batang Bawah Kakao (Theobroma cacao L.). Pelita Perkebunan 28(2): 75-84. https://doi. org/10.22302/iccri.jur.pelitaperkebunan.v28i2.200

Anwar A., Muliati, G., Wahyuni, M. (2019) Kajian Metode Evaluasi Kesesuaian Lahan untuk Kakao di Kabupaten Bantaeng. cocoa cultivation. All sampling locations in East Kolaka, covering an area of 11,213 hectares in Poli-Polia, Palenga Jaya, and Toasu village, are classified as S2 or suitable for cocoa growth. The limiting factors for the suitability of cocoa growth are humidity, effective soil depth, and $\mathrm{P}_{2} \mathrm{O}_{5}$ availability in the soil. From an economic perspective, the $\mathrm{R} / \mathrm{C}$ ratio of cocoa cultivation in North Kolaka and East Kolaka is 1.56 and 2.12, respectively. This means that cocoa cultivation in the two districts has a potency to be developed.

\section{Acknowledgements}

The authors wish to thank the Directorate of Research and Community Service, Ministry of Research, Technology and Higher Education [DRPM RISTEKDIKTI] for financing this research during the academic year 2019.

Agrotech Res J 3(2): 85-92. https://doi.org/10.20961/agrotechresj.v3i2.33174

Babalola T.S, Oso T, Fasina AS, Godonu K. (2011) Land Evaluation Studies of Two Wetland Soils in Nigeria. International Research Journal of Agricultural Science and Soil Science 1(6):193-204. 
Boix L.R., Zinck J.A. (2008) Land-Use Planning in the Chaco Plain (Burruyacu, Argentina). Part 1: Evaluating land-use options to support crop diversification in an agricultural frontier area using physical land evaluation. Environmental Management 42:10431063. https://doi.org/10.1007/s00267-008-9208-1

Direktorat Jenderal Perkebunan (DITJENBUN) (2011) Pedoman Teknis Praktek Budidaya Kakao yang Baik. Jakarta, Direktorat Jenderal Perkebunan.

Djaenuddin, D., Marwan, H., Subagjo, H. Hidayat, A. (2003) Petunjuk Teknis Evaluasi Lahan untuk Komoditas Pertanian. Balai Penelitian Tanah, Bogor.

Ermiati, Hasibuan, A.M., Wahyudi, A. (2014) Profil dan Kelayakan Usahatani Kakao di Kabupaten Kolaka, Sulawesi Tenggara. J. TIDP 1(3): 125-132. https://doi.org/10.21082/jtidp.v1n3.2014. p125-132

Erwiyono, R. (2007) Penetapan penyebab kerusakan pertanaman kakao akibat musim kemarau. Warta Pusat Penelitian Kopi dan Kakao Indonesia 23(3): 131-141.

Hardjowigeno, S. and Widiatmaka (2007) Evaluasi Kesesuaian Lahan dan Perencanaan Tataguna Lahan. Gadjah Mada University Press, Yogyakarta.

Havlin, J.L., Beaton, J.D., Tisdale, S.L., and Nelson W.L. (1999) Soil Fertility and Fertilizers. An Introduction to Nutrient Management. Sixth Ed. Prentice Hall: New Jersey.

Kementerian Perindustrian (2016) Gambaran sekilas industri kakao. Available at: www.kemenperin.go.id/PaketInformasi/ Kakao/kakao.pdf (accessed 19 october 2019).

Kurnia, H., Zainabun, Djuita, S. (2017) Evaluation Land Suitability of Cocoa Commodity (Theobroma cacao L.) Based DEPTAN (1997) in The Lutueng Village of Mane District Pidie. Jurnal Ilmiah Mahasiswa Pertanian Unsyiah 2(1): 1-10. https://doi. org/10.17969/jimfp.v2i1.2162

Liyanda, M., Karim, A., and Abubakar, Y. (2012) Analisis kriteria kesesuaian lahan terhadap produksi kakao pada tiga klaster pengembangan di Kabupaten Pidie. Jurnal Agrista 16(2): 62-79.

Nasution, Y., Fitriadi, A., Simatupang, M. (2020) Evaluasi Kesesuaian Lahan pada Tanaman Kakao (Theobroma cacao L.) Di Kecamatan Tano Tombangan Angkola Kabupaten Tapanuli Selatan. Grahatani 06(1): 881-889.

Neswati, R., Asrul, R., Molla, A., Widiayani, N., Nurqadri, S. (2019) Land Suitability for Cocoa Development in South Sulawesi: An Analysis using GIS and Parametric Approach. In: The 4th International Conference of Indonesian Society for Remote Sensing IOP Conf. Series: Earth and Environmental Science 280. https://doi.org/10.1088/1755-1315/280/1/012014
Mudgil, D. and Barak, S. (2018) Beverages: Processing and Technology. Scientific Publishers.

Ojo, A.D. and Sadiq, I. (2010) Effect of Climate Change on Cocoa Yield. Journal of Sustainable Development in Africa. 12(1).

Pusat Penelitian Kopi dan Kakao Indonesia (PPKKI) (2010) Buku pintar budidaya kakao, pp. 298, Depok: PT. Agromedia Pustaka.

Ramlan, Akram, Salapu, P. (2020) The Land Development of Cocoa Plant (Theobroma Cacao L.) Based on Land Suitability Aspect in Sigi Regency, Indonesia. International Journal of Advanced Science and Technology 29(5): 7049-7054.

Rubiyo and Siswanto (2012) Peningkatan produksi dan pengembangan kakao (Theobroma cacao L.) di Indonesia. Buletin Riset Tanaman Rempah dan Aneka Tanaman Industri 3(1): 33-48.

Safuan, L.O, Kandari, A. M. and Natsir, M. (2013) Evaluasi kesesuaian lahan tanaman kakao (Theobroma cacao L.) berdasarkan aplikasi analisis data iklim menggunakan aplikasi sistem informasi geografi. Jurnal Agroteknos 3(2): 80-85.

Setjen Pertanian (2016) Outlook Kakao. Komoditas Pertanian Subsektor Perkebunan. Pusat Data dan Sistem Informasi Pertanian. Sekretaris Jenderal-Kementerian Pertanian. ISSN 1907-1507. Available at: http://epublikasi.setjen.pertanian. go.id/ (accessed 10 August 2019).

Soekartawi (2006) Analisis Usaha Tani. UI Press, Jakarta.

Sugiyono (2001) Metode Penelitian Administrasi. Penerbit Alfabeta Bandung, Bandung.

Syarif , M.M., Rismaneswati, Asrul, L., and Kaimuddin (2020) Strategy for improving sustainable cocoa (Theobroma cacao $L$ ) plant productivity in South Sulawesi based on land suitability. In: IOP Conf. Series: Earth and Environmental Science 486. https:// doi.org/10.1088/1755-1315/486/1/012087

Tenkap, P. E and B. O. Balogun, B.O. (2020) Land suitability for cocoa production in Idanre, Ondo State, Nigeria. Journal of Agricultural Biotechnology and Sustainable Development 12(2): 19-33. https://doi.org/10.5897/ JABSD2019.0345

Tri, M.H., Bambang, H.S., Makruf, N. (2018) Evaluasi Kesesuaian Lahan untuk Tanaman Perkebunan di Wilayah Galela, Kabupaten Halmahera Utara, Provinsi Maluku Utara. Caraka Tani. Journal of Sustainable Agriculture 33(1), 68-77. https:// doi.org/10.20961/carakatani.v33i1.19298

Yatno, E. (2016) Kriteria Kesesuaian Lahan Untuk Tanaman Kakao di Kabupaten Kolaka dan Kolaka Timur, Sulawesi Tenggara. Sekolah Pascasarjana Institut Pertanian Bogor, Bogor. [Dissertation]. 